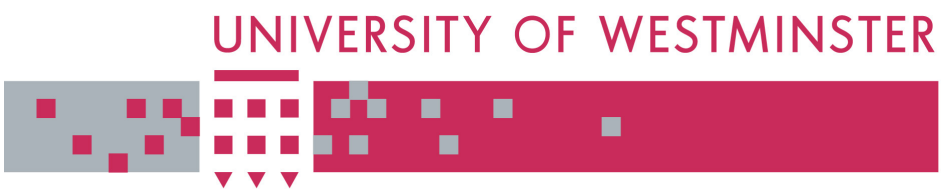

WestminsterResearch

http://www.wmin.ac.uk/westminsterresearch

\title{
Explaining party cohesion and discipline in democratic legislatures: purposiveness and contexts.
}

\author{
John E. Owens
}

School of Social Sciences, Humanities \& Languages

This is an electronic version of an article published in Journal of Legislative Studies, 9 (4). pp. 12-40, Winter 2003. Journal of Legislative Studies is available online at:

http://www.journalsonline.tandf.co.uk/openurl.asp?genre=article\&issn=1357$\underline{2334 \text { \&volume }=9 \text { \&issue }=4 \& \text { spage }=12}$

The WestminsterResearch online digital archive at the University of Westminster aims to make the research output of the University available to a wider audience. Copyright and Moral Rights remain with the authors and/or copyright owners. Users are permitted to download and/or print one copy for non-commercial private study or research. Further distribution and any use of material from within this archive for profit-making enterprises or for commercial gain is strictly forbidden.

Whilst further distribution of specific materials from within this archive is forbidden, you may freely distribute the URL of WestminsterResearch.

(http://www.wmin.ac.uk/westminsterresearch).

In case of abuse or copyright appearing without permission e-mail wattsn@wmin.ac.uk. 


\title{
Explaining Party Cohesion and Discipline in Democratic Legislatures: Purposiveness and Contexts
}

\author{
JOHN E. OWENS
}

17 Honywood Road, COLCHESTER, United Kingdom, CO3 3AS

Tel: 44 (0)207 468 2307; Fax 44 (0)207 9115164

Email: owensj@westminster.ac.uk

\begin{abstract}
Considerable advances have been made in our theoretical understanding of the behaviour of legislative parties over the last 30 or so years, particularly in purposive theory. This article reviews the current state of the literature on the important subject of legislative party cohesion. How do we explain varying levels of legislative party cohesion? In the first part of this article, I explore the difficulties encountered in identifying and measuring a dependent variable that can be applied globally and comparatively to plenary votes in democratic legislatures. The remaining discussion then reviews the extant empirical evidence on how a multiplicity of systemic, party-levels, and situational factors supposedly impact cohesion/discipline levels. The article makes clear that short-hand differences, such as those between parliamentary and supposedly presidential systems, or between different sets of election rules, do not provide complete answers because every legislative chamber has a unique set of formal and informal election rules and internal rules and procedures, is located within a different constitutional and cultural context, and subject to influences emanating from different kinds of policies. The article ends with a discussion of the possibilities and limitations of building comparative models of cohesion/discipline and suggests the direction future must take.
\end{abstract}

John E. Owens is Professor of United States Government and Politics, The Centre for the Study of Democracy, The University of Westminster, UK. 


\title{
Explaining Party Cohesion and Discipline in Democratic Legislatures: Purposiveness and Contexts
}

\author{
JOHN E. OWENS
}

Legislative party discipline and cohesion are important phenomena in the study of political systems. Unless assumptions are made that parties are cohesive and act as unified collectivities with reasonably well-defined goals, it is really difficult, if not impossible, to consider their electoral and legislative roles usefully. But levels of legislative party cohesiveness are also important because they provide us with crucial information about how legislatures/parliaments function and how they interact with executives/governments. Without cohesive (or disciplined) parties, ${ }^{1}$ government survival in parliamentary systems is threatened because executive and legislative powers are fused while in separated systems presidents' bases of legislative support become less stable. How do we explain varying levels of legislative party cohesion? In the first part of this article, I draw on the purposive literature to explore the benefits and costs to legislators in democratic legislatures of joining and acting collectively and individualistically within political parties. This discussion leads on to discussion of various conceptual and empirical problems encountered in analysing intra-party cohesion and discipline in democratic legislatures on plenary votes. Finally, the article reviews the extant empirical evidence on how a multiplicity of systemic, party-levels, and situational factors supposedly impact cohesion/discipline levels. The article ends with a discussion of the possibilities and limitations of building comparative models of cohesion/discipline.

\section{Legislative Purposiveness and Political Parties}

Although important differences remain as to whether legislators are motivated overwhelmingly by the re-election goal or by a combination of goals that also includes power and good public policy, ${ }^{2}$ most explanations argue that legislators are purposive. In order to achieve their goals, they typically join and work within political parties because parties offer the possibility of structured collective action with like-minded copartisans, instant access to and identification with a brand name that can enhance

\footnotetext{
${ }^{1}$ Although these concepts are analytically distinct, in that legislators may agree with one another ipso facto because of shared preferences (cohesion) or because they are persuaded or coerced into agreement with one another (discipline) - they are empirically indistinguishable insofar as we observe legislators voting together to some degree or another. So, a legislative party may appear disciplined in the sense that it is cohesive even though little or no coercion (discipline) has been deployed. E. Özbudun, Party Cohesion in Western Democracies: A Causal Analysis. Sage Professional Papers in Comparative Politics, 01-006, Beverley Hills, CA and London: Sage 1970: 305.

${ }^{2}$ David R. Mayhew, Congress: The Electoral Connection New Haven, CT and London, 1974; Richard F. Fenno, Congressmen in Committees, Boston and Toronto: Little Brown and Company, 1973; Lawrence C. Dodd, 'Congress and the Quest for Power' in Lawrence C. Dodd and Bruce I. Oppenheimer, eds., Congress Reconsidered. New York: Praeger: 1977 and Richard L. Hall, 'Participation and Purpose in Committee Decisionmaking', American Political Science Review 81/1, 1987: 105-28.
} 
electoral prospects, provide them with potentially significant legislative resources, including promotion to committee and leadership positions, and influence over the distribution of patronage. ${ }^{3}$ Additionally, although this view has been challenged in the context of weak congressional parties in the United States, ${ }^{4}$ and is complicated by the incidence of minority coalition governments in many parliamentary systems, ${ }^{5}$ being a member of the governing rather than the opposition party or coalition offers significantly greater benefits. ${ }^{6}$

Much empirical evidence supports the logic of legislative purposiveness. Studies of various legislatures - including the British House of Commons, the Danish Folketing, the Portuguese Assembleia, and the Slovak Národná Rada - attest to the importance of copartisans' shared policy preferences, emotional loyalties and moral commitments underpinning tight party cohesion, ${ }^{7}$ as well as to how candidate nomination or selection processes reinforce partisan proclivities. ${ }^{8}$ Even when legislative parties are not subject to

\footnotetext{
${ }^{3}$ John H. Aldrich, Why Parties? The Origin and Transformation of Party Politics in America Chicago and London: The University of Chicago Press, 1995: 21; Michael Laver and Kenneth A. Shepsle, 'How Political Parties Emerged from the Primeval Slim: Party Cohesion, Party Discipline, and the Formation of Governments' in Shaun Bowler, David M. Farrell, and Richard S. Katz, eds. Party Discipline and Parliamentary Government. Columbus, OH: Ohio State University Press, 1999: 23-48; Gary W. Cox, Making Votes Count, Strategic Coordination in the World's Electoral Systems. Cambridge and New York: Cambridge University Press, 1997; John M. Carey and Matthew S. Shugart, 'Incentives to Cultivate a Personal Vote: The Rank Ordering of Electoral Formulas', Electoral Studies 14/4, 1995: 419.
}

${ }^{4}$ Keith Krehbiel, 'Where's the Party?', British Journal of Political Science 23/1, 1993: 235-266 and Keith Krehbiel, Information and Legislative Organisation. Ann Arbor, MI: University of Michigan Press, 1991; Keith Krehbiel, 'The Party Effect from A to Z and Beyond', Journal of Politics, 61/3: 832-41.

${ }^{5}$ It is well known that the fusion of powers in parliamentary systems does not necessarily produce majority governments. See Kaare Strøm, Minority Government and Majority Rule. Cambridge and New York: Cambridge University Press, 1990: 8-9; Michael Laver and Normal Schofield, Multiparty Government: The Politics of Coalition in Europe. Oxford: Oxford University Press, 1990; and Jose Antonio Cheibub, Adam Przeworski and Sebastian M. Saiegh, 'Government Coalitions Under Presidentialism and Parliamentarism'. Paper presented to the Annual Meeting of the Midwest Political Science Association, Chicago, April 2002.

${ }^{6}$ Gary W. Cox and Mathew D. McCubbins, Legislative Leviathan. Party Government in the House Berkeley, CA and London: University of California Press, 1993; Richard Rose, The Problem of Party Government, Harmondsworth: Penguin, 1974.

77 John P. Mackintosh, The Government and Politics of Britain, $4^{\text {th }}$ edn. London: Hutchinson, 1977: 75ff; Edward Crowe, 'The Web of Authority: Party Loyalty and Social Control in the British House of Commons', Legislative Studies Quarterly, XI/1, 1986: 161-85; Walter C. Opello, 'Portugal's Parliament: An Organisational Analysis of Legislative Performance', Legislative Studies Quarterly, XI/3, 1986: 291:308; and Darina Malová and Danica Siváková, 'The National Council of the Slovak Republic: The Developments of a National Parliament' in Attila Ágh and Gabriella Ilonszki, Parliament and Organized Interests: The Second Steps, Budapest: Hungarian Centre of Democracy Studies Foundation, 1994: 354, 357 and Table 11; Asbjørn Skjæveland, 'Party Cohesion in the Danish Parliament', The Journal of Legislative Studies 7/2, 2001: 42; Christopher Kam, 'Do Ideological Preferences Explain Parliamentary Behaviour? Evidence From Great Britain and Canada', The Journal of Legislative Studies, 7/4, 2001: 115; Jonathan Malloy, 'The High Discipline and Low Ideological Cohesion of Canadian Parties', this volume and Edward Schneier, 'Party Leadership in the Emerging Parliament of Indonesia'. Paper presented to the Biannual Conference of the Research Committee of Legislative Specialists of the International Political Science Association, Bilgi University, Istanbul, Turkey, 23-26 June 2002: 17.

${ }^{8}$ E. E. Schattschneider, Party Government. New York: Holt, Reinhart and Winston, 1942: 64; Susan Scarrow, Parties and Their Members Oxford: Oxford University Press, 1996: Moshe Maor, Political Parties and Party Systems. London: Routledge, 1997; Patrick Seyd and Paul Whiteley, 'Towards a More Responsible Two Party 
tight whipping - as on many free/conscience issues ${ }^{9}$ - or where party control over nominations and cohesion is weak, shared policy preferences form an essential element of intra-party cohesion and differentiate one set of legislative copartisans from opponents. ${ }^{10}$ The importance of shared policy preferences is augmented and reinforced by party leaders' efforts - especially those of majority parties - to win collective benefits for their party by controlling parliamentary timetables, invoking votes of confidence that trump policy deliberations, deploying special rules that structure or limit debate, ${ }^{11}$ or by casting all party votes for their party; ${ }^{12}$ and by using their tactical skills to buy off dissidents, limit policy side payments (pork barrel, regulatory relief, or special executive interventions), and use their control over significant political resources (committee assignments, promotions to executive positions) to reward loyalty and sanctions to punish dissent. ${ }^{13}$ If

System. The British Party System Reconsidered. Paper presented to the annual meetings of the American Political Science Associations, Washington, DC, 31 August- 3 September 2000.

${ }^{9}$ David Marsh and John Hibbing, 'Accounting for the Voting Patterns of British MPs on Free Votes," Legislative Studies Quarterly 12/2, 1987: 275-297; Phillip Cowley, ed., Conscience and Parliament, London: Frank Cass, 1998; Philip Cowley and Mark Stuart, 'Sodomy, Slaughter, Sunday Shopping, and Seatbelts', Party Politics, 3/1, 1997: 119-30; Charles Pattie, Edward Fieldhouse and R. J. Johnston, 'The Price of Conscience: The Electoral Correlates and Consequences of Free Votes and Rebellions in the British House of Commons, 1987-92', British Journal of Political Science, 24/3, 1994: 371; Deirdre McKeown and Rob Lundie, Free Votes in Australian and Some Overseas Parliaments. Canberra: Department of the Parliamentary Library, Parliament of Australia, Current Issues Brief No.1, 2002-03, 2002; Marvin L. Overby, Raymond Tallovich and Donley T. Studlar, 'Party and Free Votes In Canada: Abortion in the House of Commons', Party Politics 4/3, 1998: 382.

${ }^{10}$ Helmut Norpoth, 'Explaining Party Cohesion in Congress: The Case of Shared Policy Attitudes', American Political Science Review, 70/4, 1976: 1156-1171; David W. Rohde, Parties and Leaders in the Postreform House: Chicago and London: University of Chicago Press, 1991; Barbara Sinclair, Legislators, Leaders, and Lawmaking. The US House of Representatives in the Postreform Era Baltimore and London: The Johns Hopkins University Press, 1995: 12-13.

${ }^{11}$ Cox and McCubbins, Legislative Leviathan: 90-102; Rohde, Parties and Leaders in the Postreform House; Sinclair, Legislators, Leaders, and Lawmaking; Stanley Bach and Steven S. Smith, Managing Uncertainty in the House of Representatives. Adaptation and Innovation in Special Rules. Washington, DC: The Brookings Institution, 1988; Gary W. Cox and Mathew D. McCubbins, 'Agenda Power in the U.S. House of Representatives, 1977-1986' and Andrea C. Campbell, Gary W. Cox, and Mathew D. McCubbins, 'Agenda Power in the U.S. Senate, 1977-1986' in David W. Brady and Mathew D. McCubbins, eds., Party, Process, and Political Change in Congress. New Perspectives on the History of Congress. Stanford, CA: Stanford University Press, 2002: 107-145 and 146-165.

${ }^{12}$ Richard S. Katz, 'Party Government: A Rationalistic Conception' in Francis G. Castles and Rudolf Wildenmann, eds., Visions and Realities of Party Government. Berlin: De Gruyter, 1996: 42ff; Strøm, Minority Government and Majority Rule; Laver and Schofield, Multiparty Government; Robert Harmel and Kenneth Janda, Parties and

Their Environments: Limits to Reform New York: Longman, 1995, ch. 6; Rose, The Problem of Party Government; John D. Huber, Rationalizing Parliament. Legislative Institutions and Party Politics in France, Cambridge and New York: Cambridge University Press, 1996, 82 ff, 279; Daniel Diermeier and Timothy J. Feddersen, 'Cohesion in Legislatures and the Vote of Confidence Procedure', American Political Science Review, 92/3, 1998: 611-622; Rudy B. Andweg and Lia Nijzink, 'Beyond the Two-Body Image: Relations Between Ministers and MPs' and Herbert Döring, 'Fewer Though Presumably More Conflictual Bills: Parliamentary Government Acting as a Monopolist' in Döring, Parliaments and Majority Rule in Western Europe; George Tsebelis, Veto Players. How Political Institutions Work. Princeton, NJ and London: Princeton University Press, 2002: 84-85; Carol Mershon and William B. Heller. 'Party Fluidity and Legislators' Vote Choices: The Italian Chamber of Deputies, 19962000.' Paper presented to the Annual Meeting of the American Political Science Association, San Francisco, CA. August 30-September 2, 2001; Mikitaka Masuyama, 'Is the Japanese Diet Consensual?', The Journal of Legislative Studies, 6/1, 2000: 18-24.

${ }^{13}$ Bjorn Erik Rasch, 'Electoral Systems, Parliamentary Committees, and Party Discipline: The Norwegian Storting in a Comparative Perspective' in Bowler, Farrell, and Katz, Party Discipline and Parliamentary Government: 121- 
cohesion is very high, sanctions become unnecessary; if it is very low, they become unenforceable. Only if cohesion is sufficiently high that copartisans are willing to grant their leaders sanction powers and low enough to make these necessary in the party's collective interests can sanctions be used. ${ }^{14}$ Studies reveal a wide range of disciplinary regimes ranging from expulsion from the party (as in the post-Communist Polish Sjem ${ }^{15}$ ) or suppression of dissent where issues threaten party unity and/or generate discomfort for the government (as in the case of the ANC in the South African Assembly ${ }^{16}$ ) to the weak regimes available to leaders in the US Senate or the Brazilian Câmara dos Deputados and Senado. ${ }^{17}$ Somewhere in between lie the disciplinary regimes within the Italian Camera dei Deputati in the late 1990s, when the imposition of discipline was always qualified by complex risk calculations that legislators would quit their parties if discipline were too strict. ${ }^{18}$ However, even where strong disciplinary powers are available, as in the British House of Commons, the degree to which they are effective will depend on the specific policy issue and other situational factors, which explains why various studies of different legislatures have shown that sanctions are often not used or used ineffectively. ${ }^{19}$

140; Michael Gallagher and Michael Marsh, eds., Candidate Selection in Comparative Perspective. The Secret Garden. London: Sage Publications, 1988; Gary W. Cox, The Efficient Secret: The Cabinet and the Development of Political Parties in Victorian England Cambridge: Cambridge University Press, 1987; William Heller, 'Making Policy Stick: Why the Government Gets What It Wants in Multiparty Parliaments', American Journal of Political Science 45/4, 2001: 780-98; Sinclair, Legislators, Leaders, and Lawmaking; Rohde, Parties and Leaders in the Postreform House; Aldrich, Why Parties? 25-26; Cox, Making Votes Count; John H. Aldrich and David W. Rohde, 'Balance of Power: Republican Party Leadership and the Committee System in the 104th House'. Paper presented to the annual meeting of the Midwest Political Science Association, Chicago, 10 -13 April 1997; Cox and McCubbins, Legislative Leviathan, 125; Sara Brandes Crook and John R. Hibbing, 'Congressional Reform and Party Discipline: The Effect of Changes in the Seniority System on Party Loyalty in the US House of Representatives', British Journal of Political Science, 15/2, 1985: 207-226.

${ }^{14}$ For a similar point, see Bowler, Farrell, and Katz, 'Party Cohesion, Party Discipline and Parliaments': 5.

${ }^{15}$ Irena Jackiewicz and Zbigniew Jackiewicz, 'The Polish Parliament in Transition: In Search of A Model' in Attila Ágh and Gabriella Ilonszki, Parliament and Organized Interests: The Second Steps, Budapest: Hungarian Centre of Democracy Studies Foundation, 1994: 373.

${ }^{16}$ Christina Murray and Lia Nijzink, Building Representative Democracy. South Africa's Legislatures and the Constitution', Cape Town: The European Union Parliamentary Support Programme, 2002: 14.

${ }^{17}$ Barbara Sinclair, 'The Senate Leadership Dilemma: Passing Bills and Pursuing Partisan Advantage in a Nonmajoritarian Chamber' in Colton C. Campbell and Nicol C. Rae, eds., The Contentious Senate. Partisanship, Ideology, and the Myth of Cool Judgement. Lanham, MD and Oxford: Rowman and Littlefield, 2001: 65-90; Scott Mainwaring and Aníbal S. Pérez-Liñán, 'Party Discipline in the Brazilian Constitutional Congress', Legislative Studies Quarterly, XXII/4, 1997: 477.

${ }^{18}$ Mershon and Heller. 'Party Fluidity and Legislators' Vote Choices': 23-24.

${ }^{19}$ Philip Cowley and Philip Norton, 'Rebels and Rebellions: Conservative MPs in the 1992 Parliament', British Journal of Politics and International Relations, 1/1, 1999: 84-105; Sam Depauw, 'Parliamentary Party Cohesion and the Scarcity of Sanctions in the Belgian Parliament, 1991-95', Res Publica, 1: 15-39; Gerhard Loewenberg, Parliament in the German Political System. Ithaca, NY: Cornell University Press, 1967: 356-5; Werner J. Patzelt, 'Party Cohesion and Party Discipline in German Parliaments', The Journal of Legislative Studies, this volume: $\mathrm{xx}$. 
Joining a legislative party and seeking to maximise the benefits of collective action, however, requires individual legislators to incur substantial transaction costs. These costs increase proportionally the greater the distance between the legislator's preferences and the legislative party's median point, the further the party's median point is from the median point of the party activists or voters in the individual legislators' constituency, ${ }^{20}$ and the greater the unpopularity of the government or majority party. ${ }^{21}$ In order to obviate or limit involvements in the cumbersome, divisive, and expensive agreementreaching processes within the party and the need to satisfy large swathes of the electorate, a legislator primarily motivated by re-election might opt instead for an individualist or factional representational strategy that entails directly and selectively compensating identifiable supporters in his/her geographic constituency with pork barrel legislation (e.g. leggini in the Italian system) or political patronage. ${ }^{22}$ Various institutional and other structures might encourage the legislator to pursue such a strategy, thereby undermining the strength of parties. In the Baltic States, Brazil, Colombia, and the United States, for example, parties simply do not provide candidates with many campaign resources (volunteers, campaign finance, consulting services, etc.) and so they must generate their own. ${ }^{23}$ In the Italian Camera dei Deputati and the Japanese Diet, such resources are provided on a localised fractional basis ${ }^{24}$ and so loyalty tends to be given to the faction, with similar consequences for party fragmentation and dissent. The absence of party resources for campaigning might be compounded by voters' ignorance of their representatives' behaviour in the legislature or lack of interest in national issues. In these circumstances, legislators will have every reason to run on local issues, rely on symbolic

\footnotetext{
${ }^{20}$ Susan Scarrow, 'The Paradox of Enrolment: Assessing the Costs and Benefits of Party Memberships', European Journal of Political Research 25/1, 1994: 45; Arthur T. Denzau, William H. Riker and Kenneth A. Shepsle, 'Farquharson and Fenno: Sophisticated Voting and Home Style', American Political Science Review, 79/4, 1985: $1118,1132$.

${ }^{21}$ Even in America's separated system, where blame avoidance for one's party performance is much easier, the president's party has historically lost congressional seats in mid-term elections.

${ }^{22}$ Sartori, Parties and Party Systems: 73; Carey and Shugart, 'Incentives to Cultivate a Personal Vote': 418-19.

${ }^{23}$ Marcus Kreuzer and Vello Pettai, 'Patterns of Political Instability: Affiliation Patterns of Politicians and Voters in Post-Communist Estonia, Latvia and Lithuania' in Studies in Comparative International Development, 38/2, forthcoming 2003; Barry Ames, 'Party Discipline in the Brazilian Chamber of Deputies' in Scott Morgenstern and Benito Nacif, eds., Legislative Politics in Latin America, Cambridge and New York: Cambridge University Press 2002: 193; Barry Ames, 'Electoral Rules, Constituency Pressures, and Pork Barrel: Bases of Voting in the Brazilian Congress', Journal of Politics, 57/2, 1995: 324-343; Rachael E. Ingall and Brian F. Crisp,

'Determinants of Home Style: The Many Incentives for Going Home in Colombia', Legislative Studies Quarterly, 26/3: 487-512; Richard F. Fenno, Home Style. House Members in Their Districts. Boston, MA and Toronto: Little, Brown and Co. 1978; Richard F. Fenno, Senators on the Campaign Trail. The Politics of Representation Norman, OK and London: University of Oklahoma Press, 1996.

${ }^{24}$ Giuseppe Di Palma, Surviving Without Governing: The Italian Parties in Parliament. Berkeley, CA: The University of California Press, 1977: 55-63; Raphael Zarinski, 'Intra-Party Conflict in a Dominant Party: The Experience of Italian Christian Democracy', Journal of Politics, 1/1, 1965: 3-33; Giovanni Sartori, Parties and Party Systems: A Framework For Analysis. Cambridge and New York: Cambridge University Press, 1976: 88-90, 90-99; Masaru Kohno, Japan's Postwar Party Politics. Princeton, NJ and London: Princeton University Press: 91-115; Gary W. Cox and Frances Rosenbluth, 'The Electoral Fortunes of Legislative Factions in Japan', American Political Science Review, 87/3, 1993: 578-579.
} 
or personal appeals, build 'personalistic proto-organisations' ${ }^{25}$ and electoral connections with their constituents that are nonpartisan or based on links with party fractions rather than a party as a whole.

So, there is a trade-off for legislators between the attractions of the collective goods offered by legislative parties - and the need, therefore, to stick with the party and sustain its cohesion - and the loss of discretion and freedom of action to follow one's conscience, to privilege loyalty to one's faction or local party activists over national legislative leaders, or represent the views of one's constituents should a conflict between these sources of influence arise. The nature of trade-offs will vary according to the institutional and other contexts, which are discussed later. Before exploring those contexts, however, let us consider how the theories rehearsed so far might be systematically tested - using some measure of cohesion to create dependent variables and the contextual factors as independent variables.

Most studies of legislative party cohesion adopt a case study approach. That is, they report information and test explanations based on single legislatures. Therein lies a major problem: almost all the findings derived from single cases are not open to refutation by counter examples, unless one takes the view that the particular system is unique, in which case the hypotheses advanced cannot be falsified.

\section{Measuring Legislative Party Cohesion}

If we are to operationalise legislative party cohesion - create a dependent variable - for the purposes of systematic comparative empirical research, key decisions need to be made about what kind of data is most appropriate and/or available. Typically, researchers resort to roll call data, which is simple, flexible, ready understandable, and hard. Scholars who focus on certain legislatures, notably the US Congress, take for granted the availability of individual legislators' yeas and nays on roll call votes; and as a consequence have developed a large sub field of research, ${ }^{26}$ although too often until quite recently the more difficult task of relating party cohesion and discipline to theoretically-driven models of individual legislators' voting calculus was given insufficient attention. ${ }^{27}$ Even a cursory investigation reveals that roll call data are not available for many democratic legislatures, at least for lengthy periods of time. ${ }^{28}$ Most votes in the Italian Camera dei Deputati were

\footnotetext{
${ }^{25}$ Kreuzer and Pettai, 'Patterns of Political Instability'.

${ }^{26}$ Melissa P. Collie, 'Voting Behaviour in Legislatures' in Gerhard Loewenberg, Samuel C. Patterson, and Malcolm E. Jewell, eds., Handbook of Legislative Research. Cambridge, MA and London: Harvard University Press, 1985: 471-518.

${ }^{27}$ Aage R. Clausen, 'The Measurement of Legislative Group Behavior', Midwest Journal of Political Science 11/2, 1967: 212-24.

${ }^{28}$ Within Europe, data are available for Austria, Belgium, Britain, the Czech Republic (1993-98), Denmark, Finland, Germany (between 1970 and 1973), Greece, Iceland, Ireland, Italy, Luxembourg, The Netherlands, Norway, Poland, Portugal, Russia (1996-97), Spain, Sweden, and Switzerland. Data are also available for
} 
taken by secret ballot before 1988, and not recorded. In the Dutch Tweede Kamer, the French Assemblée Nationale (under the Fourth Republic), the German Bundestag, the New Zealand House of Representatives, the Spanish Congreso de los Diputados, the Venezuelan Asamblea Nacional, and other legislative chambers, party leaders cast votes for the entire party and only the positions of parties is recorded. ${ }^{29}$ Indeed, for most of the time most voting in most legislative chambers is semi-open or anonymous. ${ }^{30}$

But, apart from problems regarding the availability of roll call data, there are other important questions of comparability - because the compositions of data sets vary according to differences in legislative rules and decisionmaking styles, technology, patterns of legislative organisation, and party competitiveness - and reliability, in terms of whether roll call data accurately capture patterns of intra-party cohesion. In some legislative chambers, literally thousands of votes are recorded each year, in others, less than $50 .{ }^{31}$ Legislative voting rules vary considerably: whether proxy voting is allowed (as in the New Zealand House), how absences are treated, ${ }^{32}$ and which votes are subject to

Argentina, Australia (1996-98), Brazil, Canada (1994-97), Chile, Costa Rica, Guatemala, Israel (1999), Mexico (1998-2000), New Zealand (1990-94), Nicaragua, Peru (1999-2001), the Philippines (1995-98), and Uruguay. See Thomas Saalfeld, 'On Dogs and Whips: Recorded Votes' in Herbert Döring, ed., Parliaments and Majority Rule in Western Europe, Frankfurt and New York: Campus Verlag/St Martin's Press, 1995 and 1996: 535, 548-49; Kam, 'Do Ideological Preferences Explain Parliamentary Behaviour?': 89-126; John M. Carey. 'Getting Their Way, or Getting in the Way? Presidents and Party Unity in Legislative Voting.' Paper prepared for delivery at the 2002 Annual Meeting of the American Political Science Association, Boston, August 29-September 1, 2000 : Table 2.

${ }^{29}$ Rudy B. Andeweg, 'Executive Legislative Relations in the Netherlands: Consecutive and Coexisting Patterns', Legislative Studies Quarterly, 17/2, 1992: 167; Manuel Sanchez de Dios, ' Parliamentary Party Discipline in Spain' in Bowler, Farrell, and Katz, Party Discipline and Parliamentary Government; Michael Coppedge, Strong Parties and Lame Ducks: Presidential Partyarchy and Factionalism in Venezuela. Stanford, CA: Stanford University Press, 1994.

${ }^{30}$ Other legislatures, including chambers in Austria, Belgium, Bulgaria, Chile, Estonia, Italy, Lithuania, Portugal, Slovenia, and Spain, continue to permit secret voting on certain votes. Chambers in Argentina, Bolivia, Costa Rica, Ecuador, Peru, and Uruguay impose restrictions on calling for roll call votes, which in some cases are severe. Saalfeld, 'On Dogs and Whips': 535; John M. Carey, 'Visible Votes: Recorded Voting and Legislative Accountability in Latin America'. Paper presented to the conference on Exporting Congress? The Influence of the US Congress on World Legislatures, Gordon Institute for Public Policy and Citizenship Studies, Florida International University, Miami, FL, 6-7 December 2002: 8. In the New Zealand case, however, individual MPs may cast votes against their party once the 'party votes' have been taken. Fiona Barker and Stephen Levine, 'The Individual Parliamentary Member and Institutional Change: The Changing Role of the New Zealand Member of Parliament' in Lawrence D. Longley and Reuven Y. Hazan, eds., The Uneasy Relationships Between Parliamentary Members and Leaders. London and Portland, OR: Frank Cass, 2000: 118.

${ }^{31}$ The extreme cases appear to be the post-communist Russian Duma (which recorded 2.600 votes in its first year) and the Czech Poslanecka Snemovna - but recorded votes in the British House of Commons, the Danish Folketing, the Israeli Knesset, the Norwegian Storting, the Polish Sejm and the Swedish Riksdag also usually exceed 1000 votes per session. At the other extreme, however, votes were rarely recorded in the Argentine Cámara de Diputados, the Austrian Nationalrat, the Colombian Cámara de Representantes, the Costa Rican Asamblea Legislativa, the German Bundestag (in the 1960s and 1970s), the Guatemalan Congreso, the Indonesian Dewan Perwakilan Rakyat (House of People's Representatives) the South African National Assembly, and the Uruguayan Parlamento. See Saalfeld, 'On Dogs and Whips': 538; Thomas F. Remington and Steven S. Smith, 'The Development of Parliamentary Parties in Russia', Legislative Studies Quarterly XX/4, 1995: 476; Carey, 'Visible Votes': 33; Özbudun, Party Cohesion in Western Democracies.

${ }^{32}$ In many legislatures, absences are recorded leaving the researcher to figure out how to treat them. In the Danish Folketing, however, absences are not recorded whereas in the Russian Duma, non-voting is counted as a nay vote and is very commonly used (especially by right wing and party-list deputies) because successful motions must 
roll call votes, which in turn is affected by aspects of legislative organisation within the chamber. For example, in the US House and Senate and the Brazilian Câmara dos Deputados unresolved issues are allowed to proceed to the floor, allowing sometimes hundreds of floor amendments to be offered, which are subject to roll call votes; whereas in most parliamentary systems there is much tighter agenda control. In the contemporary Italian Camera dei Deputati and Senato, there are numerous problems to do with the discretion given to committees to make final voting dispositions, the use of floor votes only to approve final laws, and the high incidence of party switching (discussed later), as well as the continued use of secret voting. The peculiarities of voting rules in different legislative chambers then render comprehensive crossnational or longitudinal analysis based on roll call data extremely problematic, if not impossible. For these reasons, many scholars resort to other data. ${ }^{33}$

Even when roll call data are available, measuring party cohesion and discipline solely through roll call analysis throws up some well-known problems. Although the data are hard, because they measure voting only at the floor stage of decisionmaking, they may not tap important intra-party or inter-party differences present at the pre-floor stages. Secondly, by definition roll calls record only legislators' visible preferences. Legislators are able to voice dissent by other means, as for example through early day motions in the British House of Commons, private members' initiatives or amendments, or through informal channels. ${ }^{34}$ But, more importantly, the sample of roll call votes in a legislative session is necessarily selective. Much legislative activity involves nondecisionmaking, which touches on the important role played by legislative leaders of the governing coalition - not only in manipulating rules and procedures to structure legislative choices and shape legislation but in keeping issues that entail considerable political risks off the legislative agenda: allowing a floor debate and votes on some issues would publicise significant intra-party divisions, perhaps offer opportunities for the minority party to forge bipartisan coalitions with dissidents, and damage the party's legislative reputation. ${ }^{35}$

receive support from a majority of the Duma's total membership, not just those present. Skjæveland, 'Party Cohesion in the Danish Parliament': 36; Remington and Smith, 'The Development of Parliamentary Parties in Russia': 478, 476-77.

33 Marco Giuliani, 'Measures of Consensual Law-Making: Italian Consociativismo', South European Society and Politics 2/1, 1997: 66-96; James L. Newell, 'Turning Over a New Leaf? Cohesion and Discipline in the Italian Parliament', The Journal of Legislative Studies, 6/4, 2000: 29-52, especially 36 and 39; Mershon and Heller. 'Party Fluidity and Legislators' Vote Choices': 5-8; and William B. Heller and Carol Mershon, 'Dealing in Discipline: Party Switching and Legislative Voting in the Italian Chamber of Deputies, 1996-2000'. Paper presented to the annual meetings of the Midwest Political Science Association, Chicago, IL, April 2002.

${ }^{34}$ J. Leece and Hugh Berrington, 'Measures of Backbench Attitudes by Guttman Scaling of Early Day Motions: A Pilot Study, Labour 1968-69', British Journal of Political Science, 7/4, 1977: 529-49; Edward Crowe,

'Consensus and Structure in Legislative Norms: Party Discipline in the British House of Commons', Journal of Politics 45/4, 1983: 907-31; Ingvar Mattson, 'Private Members' Initiatives and Amendments' in Herbert Döring, ed., Parliaments and Majority Rule in Western Europe, Frankfurt and New York: Campus Verlag/St Martin's Press, 1995 and 1996: 448-87.

${ }^{35}$ Herbert Döring, 'Is Government Control of the Agenda Likely to Keep "Legislative Inflation" at Bay?' in Döring, Parliaments and Majority Rule in Western Europe: 654-87; Tsebelis, Veto Players: 82-84, 93-115; Sinclair, Legislators, Leaders, and Lawmaking: 53-60, 158-160; Huber, Rationalizing Parliament, 82 ff; Ana 
In the extreme, nondecisionmaking degenerates into Di Palma's 'surviving without governing' phenomenon; where the apparent cohesion of the Italian parliamentary parties is a façade that conceals highly factionalised and polarised parties, the near absence of major governance decisions, and governments' lack of authority over their own parliamentary coalitions. ${ }^{36}$ To a certain extent, the incidence of universalistic or 'hurrah' voting - as in the United States Congress - also imports biases into roll call analyses. ${ }^{37}$

Thirdly, in any systematic comparative inquiry controls need to be entered that make distinctions between those roll call votes that induce leadership involvement and/or discipline, and those that do not. The former are likely to be the most useful to researchers interested in leaders' abilities to discipline copartisans, so long they can be certain that supposedly free votes were not whipped. ${ }^{38}$ The latter - which will include votes on such issues as abortion, genetic engineering, stem cell research, homosexuality, and war - are more interesting to analysts focussing on copartisans' policy preferences. ${ }^{39}$ However, the distinctions do not end there. Votes on important and politically salient issues necessitate major active involvement/whipping by governing party/coalition leaders (and presidents, in separated systems) where those issues divide the major parties/coalitions - because they risk the reputation of the governing party/coalition and constitute de facto or de jure confidence votes, possibly precipitating dissolution and elections in a parliamentary system or ceding potential political advantage to the minority party in a separated system (which may also hold the presidency). Other major politically salient issues may not necessitate whipping either because copartisans are already predisposed to supporting the party position or because legislative leaders have calculated that they could relax discipline and permit dissent in the certain knowledge that they already have enough votes to avoid damaging the party's reputation, or because the opposing parties/coalitions do not oppose the position of the governing party or coalition.

Finally, assuming roll call analysis is contemplated, there are important methodological issues. Lowell's concept of a 'party vote', defined as a vote where $90 \%$ of one party

María Mustapic, 'Oscillating Relations: President and Congress in Argentina' in Morgenstern and Nacif, Legislative Politics in Latin America: 37-43.

${ }^{36}$ Di Palma, Surviving Without Governing; Giuliani, 'Measures of Consensual Law-Making': 85.

${ }^{37}$ Melissa P. Collie, 'Universalism and the Parties in the US House of Representatives, 1921-1980', American Journal of Political Science, 32/4, 1998: 865-83.

${ }^{38}$ For example, Wearing's study specifically excludes free or conscience votes. Joseph Wearing, 'Tweaking the Whips: Modified Rebelliousness in the Canadian House of Commons'. Paper presented to the Third Workshop of Parliamentary Scholars and Parliamentarians, Wroxton, UK, August 1998: Table 2. Other studies focus on them exclusively.

${ }^{39}$ Marsh and Hibbing, 'Accounting for the Voting Patterns of British MPs on Free Votes'; David Marsh and Melvyn Read, Private Members' Bills, Cambridge: Cambridge University Press, 1988; Cowley, Conscience and Parliament; Overby, Tallovich and Studlar, 'Party and Free Votes In Canada'. 
opposes $90 \%$ of the opposing party ${ }^{40}$ has the advantage of pointing up differences across legislatures dominated by two parties (e.g. Britain and the United States) but is unworkable for most European multi-party chambers. Moreover, its $90 \%$ party level threshold is arbitrary, ignores votes where party cohesion is weak, and therefore cannot tap longitudinal changes in party cohesion over time, say, from $50 \%$ to $89 \%$. Congressional Quarterly's uses the notoriously lower 50\% versus 50\% measure in the United States, which has the effect of inflating the unity of congressional parties. ${ }^{41}$ Even lower thresholds designed to accommodate multiparty legislatures are equally problematic, and make crossnational comparison impossible or of limited value. ${ }^{42}$ Other studies that use individual roll calls as the unit of analysis and then calculate cohesion coefficients on the basis of probability theory ${ }^{43}$ allow comparison of cohesion across different policy issues and across parties but do not take account of consensual voting, do not provide measures of individual legislators' party loyalty, and contain significant statistical biases. ${ }^{44}$ Where researchers use these or similar indices or W-NOMINATE factor scores, ${ }^{45}$ they typically do not distinguish between minor and major issues. ${ }^{46}$

Notwithstanding the difficulties in operationalising and measuring party cohesion for comparative analysis of democratic legislatures - whether using roll call data, surveys of legislators, or other measures - it is clear that a) the vast majority of legislators accept the benefits of joining and organising legislative parties. (In a sample of 18 legislatures, less than $1 \%$ were independents - the outliers being Ireland and Japan) $;{ }^{47}$ and b) most legislators cohere strongly with their copartisans. Space prohibits the presentation of these data but suffice to state that the most prominent incohesive legislative parties are

\footnotetext{
${ }^{40}$ A. Lawrence Lowell, The Government of England New York: Macmillan, 1908, Vol. II: 71-100.

${ }^{41}$ Lee F. Anderson, Meredith W. Watts, and Allen R. Wilcox, Legislative Roll Call Analysis, Evanston, IL: Northwestern University Press, 1966: 54; David W. Brady, Joseph Cooper, and Patricia A. Hurley, 'The Decline of Party in the US House of Representatives, 1887-1968', Legislative Studies Quarterly 4/3, 1979.

${ }^{42}$ Mainwaring and Pérez-Liñán, 'Party Discipline in the Brazilian Constitutional Congress': 460.

43 Stuart A. Rice, 'The Behavior of Legislative Groups', Political Science Quarterly 40/1, 1925: 60-72; Anderson, Watts, and Wilcox, Legislative Roll Call Analysis: 16-18, 36.

${ }^{44}$ Scott W. Desposato, 'Correcting for Bias in Roll Call Cohesion Scores'. Working Paper, Department of Political Science, University of Arizona, 2002.

${ }^{45}$ Julius Turner and Edward V. Schneier, Party and Constituency: Pressures on Congress. Revised edition. Baltimore, MD and London: The Johns Hopkins Press, 1970: 112-14; Remington and Smith, 'The Development of Parliamentary Parties in Russia', 486; Mershon and Heller, 'Party Fluidity and Legislators' Vote Choices'; Scott W. Desposato, 'SMD and Weak Political Parties'. Working Paper, Department of Political Science, University of Arizona, 2001.

${ }^{46}$ cf. Cox and McCubbins, Legislative Leviathan: 137-141.

${ }^{47}$ Kaare Strøm, 'Parties at the Core of Government' in Russell J. Dalton and Martin P. Wattenberg, Parties without Partisans. Political Change in Advanced Industrial Democracies. Oxford and New York: Oxford University Press, 2000: Table 9A.
} 
found in Brazil, Colombia, Ecuador, Estonia, Guatemala, Honduras, France (1945-1968), Italy, Japan, the United States, and Uruguay. ${ }^{48}$

Before discussing the influence of various contextual factors on cohesion, let us consider a second dependent variable that provides valuable insights into the dynamics of intraparty cohesion and discipline. This is the strategy of exit. Quite simply, some legislators are unwilling to pay the transaction costs of belonging to one legislative party and opt for a more extreme form of dissent that involves switching their allegiance to another party. As we will see, the phenomenon is quite common in the newly democratic legislatures of eastern and central Europe and Latin America, as well as in some moderately old democracies, including Italy and Japan.

\section{Party Switching}

Although there is no reliable crossnational data or study of switching, the literature shows considerable divergence across democratic legislatures: whereas just 31 British MPs switched parties between 1950 and 1996, just 20 members of the United States House and Senate between 1947 and 1997, only four Canadian MPs between 1997-2000, five members of the Norwegian Storting in the 1990s, and no members of the Finnish Eduskunta, ${ }^{49}$ 'faction hopping or parliamentary tourism' has been rife elsewhere, at least during specific periods. The phenomenon is particularly strong in the Brazilian Câmara dos Deputados, the Colombian Cámara de Representantes, the Ecuadorian Congreso, the post-Nazi German Bundestag, the post-Suharto Indonesian Dewan Perwakilan Rakyat, the Israeli Knesset, the Italian Camera dei Deputati and the Senato, the Japanese Diet, the post-apartheid South African National Assembly, and in a host of post-communist legislative chambers in Russia, eastern and central European and the Baltic states. ${ }^{50}$ In

\footnotetext{
${ }^{48}$ Duncan MacRae, Parliament, Parties and Society in France, 1946-1958. New York: St Martin's Press, 1967; Kirk Hawkins and Scott Morgenstern, 'Cohesion of Legislators in Latin America: Patterns and Explanations'. Paper delivered to the annual meetings of the American Political Science Association, Washington, DC, 30 August - 3 September 2000; Fatima Garcìa Dìez, 'Electoral Reforms and Central American Legislative Party Systems'. Paper presented to the Joint Sessions of ECPR Workshops, Grenoble, 6-11 April 2001: 5; Brady, Cooper, and Hurley, 'The Decline of Party in the US House of Representatives'; David W. Brady and Charles S. Bullock III, 'Party and Factional Organization in Legislatures', Legislative Studies Quarterly VIII/ 4; Samuel C. Patterson and Gregory Caldeira, 'Party Voting in the United States Congress', British Journal of Political Science, 18/1, 1988: 111-131. I am grateful to numerous legislative scholars for detailed information provided in private communications on legislative voting procedures, party cohesion, and switching. These include Stan Bach, Marco Giuliani, Miriam Golden, Reuven Hazan, Dobrin Kanev, Elizabeth Kirn, Lukás Linek, Alvidas Lukosaitis, Irmina Matonyte, Lia Nijzink, Chan Wook Park, Werner Patzelt, Asbjørn Skjaeveland, Ned Schneier, Matti Wiberg, and Drago Zajc.

49 Philip Cowley, 'Crossing the Floor: Representative Theory and Practice in Britain', Public Law, 1996: 214224; Malloy, 'Explaining High Discipline and Low Ideological Cohesion': 10; Personal communication, Matti Wiberg, 3 February 2002; Timothy P. Nokken, 'Dynamics of Congressional Loyalty: Party Defection and RollCall Behavior, 1947-97', Legislative Studies Quarterly, 25/3: 414-444.

${ }^{50}$ Attila Ágh, 'Change and Continuity Among the Members of Parliament: Low Incumbent Retention Rates in the New East Central European Parliaments' in Lawrence D. Longley, Attila Ágh, and Drago Zajc, eds., Parliamentary Members and Leaders - The Delicate Balance. Working Papers on Comparative Legislative Studies IV. Appleton, WI: Research Committee of Legislative Specialists, 2001: 26; Attila Ágh, 'The Parliamentarization of the East Central European Parties: Party Discipline in the Hungarian Parliaments, 1990-1996' in Bowler, Farrell, and Katz,
} 
one particularly egregious case, a Czech MP changed his party affiliation three times in the space of just one year. ${ }^{51}$

Why do legislators switch parties? First, it is important to note that many party switches are to parties within the same ideological 'family' or major coalition groups. ${ }^{52}$ Although these cases highlight parties' weak boundaries in these chambers, when they are eliminated from an analysis, the effect is to reduce switching levels to levels similar to those found in Britain and Canada. Second, following the purposive logic, legislators switch if they perceive that their goals are not well served by their existing partisan affiliation and they perceive the transaction costs incurred in switching (including various institutional rules, being part of the governing coalition, levels of partisanship among the voters, and other features of the party system) are not high. So, in Australia, Britain, Canada, South Africa, and most west European systems switchers lose the party's nomination and their seats, either immediately or at the next election (unless some fudge is agreed, as in the South African case), ${ }^{53}$ as well as their credibility with the voters, because they are elected essentially as party representatives rather than because of their individual qualities. Similarly, many conservative southern Democrats in the US House of Representatives (who were ideologically closer to the Republican Party than to their northern liberal colleagues) were until very recently prevented from switching by the benefits of being

eds. Party Discipline and Parliamentary Government. Kreuzer and Pettai, 'Patterns of Political Instability': 6-11 and Table 1; Andrés Mejía-Acosta, 'Explaining Camistetazos: The Logic of Party Switching in Ecuadorian Congress, 1979-1996. Paper presented to the annual meeting of the Midwest Political Science Association, Chicago, IL, 15-17 April 1999: 3; Peter Schindler, ed., Datenhandbuch zur Geschichte des Deutschen Bundestages, Vol. II: 939 quoted in Patzelt, 'Party Cohesion and Party Discipline in German Parliaments": this volume xx; Malová and Siváková, 'The National Council of the Slovak Republic': 354, 357 and Table 11; Personal communication, Alvidas Lukosaitis, 14 February 2003; Bernard Grofman, Evald Mikkel, and Rein Taagepera, 'Fission and Fusion of Parties in Estonia', Journal of Baltic Studies, 31/4, 2000: 329-57; Panduan Parleman Indonesia (Indonesian Parliamentary Almanac): 1236 quoted in Schneier, 'Party Leadership in the Emerging Parliament of Indonesia': Table 2; Reuven Y. Hazan, Personal Communication, 13 February 2003; Reuven Y. Hazan, 'The Israeli Mixed Electoral System: Unexpected Cumulative and Reciprocal Consequences' in Matthew S. Shugart and Martin P. Wattenberg, eds. Mixed-Member Electoral Systems: The Best of Both Worlds? New York: Oxford University Press, 2001: 362; Junko Kato, 'When the Party Breaks Up: Exit and Voice Among Japanese Legislators', American Political Science Review, 92/4, 1998: 857-870; Scott Desposato, 'Parties For Rent? Ambition, Ideology, and Party Switching in Brazil's Chamber of Deputies'. Department of Political Science, University of Arizona. Working Paper, May 2002: 4; Mershon and Heller, 'Party Fluidity and Legislators' Vote Choices': 5-8: 12-13; Moshe Haspel, Thomas F. Remington, and Steven S. Smith, 'Electoral Institutions and Party Cohesion in the Russian Duma', Journal of Politics, 60/2, 1998: 417-39; Matthijs Bogaards, 'Power-Sharing in South Africa: The ANC as a Consociational Party?' Paper presented to the conference on Power-Sharing to Democracy: Post Conflict Institutions in Ethnically Divided Societies, University of Western Ontario, 8-10 November 2002: 8 .

${ }^{51}$ Jana Reschová and Jindriska Syllová, 'The Legislature of the Czech Republic' in Ágh and Ilonszki, Parliament and Organized Interests: 331.

${ }^{52}$ Newell, 'Turning Over a New Leaf?': 43; Goldie Shabad and Kazimierz M. Slomczynski. 'Inter-Party Mobility Among Political Elites in Post-Communist East Central Europe'. Paper presented to the Annual Meetings of the American Political Science Association, San Francisco, CA, 29 August - 2 September 2001: 25; Kreuzer and Pettai, 'Patterns of Political Instability'.

${ }^{53}$ South African electoral law requires members who cross the floor to lose their seats parliamentary seats remain formally occupied by members' original parties. Murray and Nijzink, Building Representative Democracy: 12-13. 
members of the majority party almost without interruption between 1932 and 1994, better access to federal largess and greater policy influence (notably on civil rights) than they would have had if they had switched to the 'permanent' Republican minority. Once, however, Republican voting in the south increased, transaction costs were reduced, and so the incidence of switching increased, albeit marginally. More generally, however, in open and uncertain political markets of the kind found in many Latin America and postcommunist legislatures in the Baltic and eastern and central Europe - where electoral support for parties is volatile and/or party systems are shifting, where boundaries between parties are fluid, where parties provide very few electoral resources, are weakly institutionalised and lack ideological distinctiveness, where conflictual relations between executive and legislatures inhibit party responsibility, and where legislators are guaranteed nomination for re-election even if they switch parties - the transaction costs are much lower, the ties between legislators and their parties are much weaker, and the incentives to switch parties or become independents are higher. ${ }^{54}$ Under such conditions, legislators do not develop strong incentives to invest in their parties or stick with them. Instead, they become vulnerable to vote buying and better offers of institutional position or access to government largess (for example, by joining the majority or presidential party/coalition), which are made all the more attractive by their closer policy affinity to the new party; ${ }^{55}$ or they are persuaded to switch by a combination of policy considerations and better electoral opportunities, which might be related to constituency demands; ${ }^{.6}$ or they prefer to switch to a larger party. ${ }^{57}$ The consequences of switching - or the threat of switching are that party leaders become less able to develop coherent policy agendas, less able to forge intra- and inter-party majority/governing coalitions, and less able to impose strong

\footnotetext{
${ }^{54}$ See literature quoted in fns. 48 and 50 and Scott Mainwaring and Matthew S. Shugart, 'Presidentialism and the Party System' in Scott Mainwaring and Matthew S. Shugart, eds., Presidentialism and Democracy in Latin America. Cambridge and New York: Cambridge University Press, 1997.

55 Ames, 'Party Discipline in the Brazilian Chamber of Deputies': 193-194; David J. Samuels, 'Progressive Ambition, Federalism, and Pork-Barreling in Brazil' in Morgenstern and Nacif, Legislative Politics in Latin America: 320-340; Arturo Valenzuela, Political Brokers in Chile: Local Government in a Centralized Polity. Durham, NC and London: Duke University Press; Giuliani, 'Measures of Consensual Law-Making': 69; Di Palma, Surviving Without Governing: 55-63; Miriam Golden, 'Electoral Connections: The Effects of the Personal Vote on Political Patronage, Bureaucracy and Legislation in Postwar Italy', British Journal of Political Science, 33/2: 2003: $189-212$.

${ }^{56}$ Steven R. Reed and Ethan Scheiner, 'Electoral Incentives and Policy Preferences: Mixed Motives Behind Party Defections in Japan', British Journal of Political Science, 33/2: 189-212; Shabad and Slomczynski. 'Inter-Party Mobility Among Political Elites in Post-Communist East Central Europe'; Hazan, 'The Israeli Mixed Electoral System'; Mainwaring and Pérez-Liñán, 'Party Discipline in the Brazilian Constitutional Congress': 470; Kreuzer and Pettai, 'Patterns of Political Instability', forthcoming;

${ }^{57}$ Mershon and Heller, 'Party Fluidity and Legislators' Vote Choices'; László Szarvas, 'European Standards in the Hungarian Parliamentary Party System' in Ágh, The Emergence of East Central European Parliaments; Mark P. Jones, Electoral Laws and the Survival of Presidential Democracies. Notre Dame, IN: The University of Notre Dame Press, 1995.
} 
constraints on their copartisans. If they do seek greater intra-party coherence, they risk permanent defections to other parties. ${ }^{\mathbf{5 8}}$

What contextual factors then affect legislators' proclivity to stick with their parties? A priori, we should expect the political decisions of purposive legislators in democratic legislatures to be constrained by a range by factors to do with the political system in which they operate, the party to which they are affiliated, and the peculiarities of the decisionmaking situation - which together comprise the legislators' strategic environment and structure choices that they and their colleagues must make.

\section{System Context}

Legislators' propensities to address collective action and social choice problems through their party will vary according to the resources that they can marshal and the incentive structures provided by different institutional and situational contexts. All political systems are different, as are legislators' host parties and the specific situation that they encounter at any given time.

\section{System Stability and Maturity}

Legislators need time and resources to build party and other organisations and to coordinate agreement around a common programme. A priori, it seems plausible that the maturity and stability of a democratic regime would affect the level of party cohesion and party fluidity - because the content of party reputations would be more uncertain and contestable in the earlier years than subsequently, in part because of the previous system's legacies. ${ }^{59}$ To take an extreme example, in post-communist Russia, there was no pre-existing organized opposition movement or party system or no negotiated transition where relatively organized opposition forces bargained with leaders of the previous regimes over the nature of new parliamentary institutions, as there was in eastern Europe. As a consequence, even after the emergence of more democratic processes in Russia, basic institutional arrangements remained unsettled, particularly in relation to Dumapresidential relations, and Russian voters exhibited considerable fluidity and instability in their partisan and policy preferences. ${ }^{60}$ As in other post-authoritarian emerging democratic regimes - in Germany, the Baltic States, eastern and central Europe, and Latin America - parliamentary representatives were uncomfortable with the concept of 'party', wary of individual party reputations, and experienced extreme difficulty in settling their

\footnotetext{
${ }^{58}$ David M. Olson, 'Party Formation and Party System Consolidation in the New Democracies of Central Europe', Political Studies, 46/3, 1996: 439-41; Shabad and Slomczynski. 'Inter-Party Mobility Among Political Elites in Post-Communist East Central Europe': 24; Shaun Bowler, 'Parties in Legislatures: Two Competing Explanations' in Dalton and Wattenberg, Parties without Partisans: 178.

${ }^{59}$ Kitschelt and Smyth, 'Programmatic Party Cohesion in Emerging Post Communist Democracies'.

${ }^{60}$ Remington and Smith, 'The Development of Parliamentary Parties in Russia': 481-83.
} 
loyalty to different parties and the executive. ${ }^{61}$ Similarly, when a pre-existing party system is decaying, as in France during the $4^{\text {th }}$ Republic ${ }^{62}$ or Italy or Japan in the $1990 \mathrm{~s}^{63}$ - or realigning, as for example in the United States in the 1850s or after the 1970s in the south $^{64}$ - political instability and party fluidity increases, and legislative party cohesion remains low: purposive legislators want to survive politically, so they dissent from their copartisans, sometimes develop individualistic electoral connections, sometimes switch parties, ${ }^{65}$ and sometimes opt out of the system altogether as legislative careers lose their value. $^{66}$

Yet, system immaturity and instability cannot be a sufficient condition for low legislative party cohesion or party fluidity. For, important variations have been found across transition systems - for example, in Latin America between Brazil and Argentina, in eastern Europe between legislatures in Polish, the Czech Republic, and Slovenia, ${ }^{67}$ and in the Baltic states between Latvia and Estonia. Moreover, as Sartori has argued, in mature

\footnotetext{
${ }^{61}$ David M. Olson, Democratic Legislative Institutions: A Comparative View. Armonk, NY: M. E. Sharpe, $1994:$ 122; Attila Ágh, 'Change and Continuity Among the Members of Parliament: Low Incumbent Retention Rates in the New East Central European Parliaments' in Lawrence D. Longley, Attila Ágh, and Drago Zajc, eds., Parliamentary Members and Leaders - The Delicate Balance. Working Papers on Comparative Legislative Studies IV. Appleton, WI: Research Committee of Legislative Specialists, 2001: 26; Loewenberg, Parliament in the German Political System: 45; Irena Jackiewicz, 'The Polish Parliamentarians under Post-Communism: The Antimony of Representation' in Attila Ágh, ed., The Emergence of East Central European Parliaments: The First Steps, Budapest: Hungarian Centre of Democracy Studies Foundation, 1994: 262; Paul G. Lewis, ed., Party Development and Democratic Change in Post-Communist Europe. The First Decade. London and Portland, IR: Frank Cass, 2001; Morgenstern and Nacif, Legislative Politics in Latin America.

${ }^{62}$ MacRae, Parliament, Parties and Society in France; Philip E. Converse and Roy Piere, 'Representatives Roles and Legislative Behavior in France', Legislative Studies Quarterly IV/4, 1980: 525-62; David M. Wood and Jack T. Pitzer, 'Parties, Coalitions, and Cleavages: A Comparison of Two Legislatures in Two French Republics', Legislative Studies Quarterly, 4/2, 1979: 197-226

${ }^{63}$ Giliberto Capano and Marco Giuliani, 'Governing Without Surviving? An Italian Paradox: Law-Making in Italy, 1987-2001', The Journal of Legislative Studies, 7/4, 2001: 16-17, 30-33; Vincent Della Sala, 'The Italian Parliament: Chambers in a Crumbling House' in Philip Norton, ed., Parliaments and Governments Western Europe. Parliaments in Contemporary Western Europe, Vol. 1, London and Portland, OR: Frank Cass, $1998: 81$.

${ }^{64}$ Aldrich, Why Parties?: 53-56.

${ }^{65}$ Capano and Giuliani, 'Governing Without Surviving?': 32; Newell, 'Turning Over a New Leaf?' 43; Reed and Scheiner, 'Electoral Incentives and Policy Preferences'.

${ }^{66}$ John M. Carey, Term Limits and Legislative Representation. Cambridge and New York: Cambridge University Press, 1996; Robert H. Dix, 'Incumbency and Electoral Turnover in Latin America' in Jorge I. Dominguez, ed., Parties, Elections, and Political Participation in Latin America. New York: Garland Publishing, 1994; Nelson W. Polsby, 'The Institutionalization of the House of Representatives', American Political Science Review 62/1: 144-68; Kato, 'When the Party Breaks Up'.

${ }^{67}$ Michael Coppedge, 'The Dynamic Diversity of Latin American Party Systems', Party Politics, 4/4, 1998: 547568; Kenneth M. Roberts and Erik Wibbels, 'Party Systems and Electoral Volatility in Latin America: A Test of Economic, Institutional, and Structural Explanations', American Political Science Review, 93/3, 1999: 575-590; Shabad and Slomczynski. 'Inter-Party Mobility Among Political Elites in Post-Communist East Central Europe': 8-11 and Tables 1 and 2; Vello Pattai and Marcus Kreuzer, 'Institutions and Party Development in the Baltic States' in Paul G. Lewis, ed., Party Development and Democratic Change in Post-Communist Europe. The First Decade. London and Portland, IR: Frank Cass, 2001; 123-24; and Kreuzer and Pettai, 'Patterns of Political Instability'.
} 
party systems where the same party wins elections repeatedly over time - as, for example, in post-war Italy or Japan - party leaders will find it difficult to dissuade legislators from pursuing individualistic representational strategies associated with patronage and clientelism (state jobs, social housing allocations, government contracts, and so forth), to prevent factionalism and impose party discipline when the party has little prospect of losing. ${ }^{68}$

Let us turn now to institutional explanations, which are the most common in the literature.

\section{Electoral Rules}

Politicians' purposive strategies are affected by electoral rules and norms that govern who becomes a candidate, what types of campaign activity are permitted and encouraged, and how the ballot is structured. Institutionalist explanations of legislative party cohesion and discipline pay considerable attention to ballot structure. Specifically, where electoral institutions force legislators to compete with copartisans for preference votes, where there is no provision for pooling votes within entire party lists, where party leaders exert weak control over nominations, and where constituencies tend to be numerically larger, legislators tend to pursue individualistic rather than collective electoral and legislative strategies. So, where voters in multi-member districts are allowed to vote for individual candidates rather than party lists, legislative candidates and party factions develop strong incentives to compete with one another for the support of party voters rather than as representatives of a single collective brand name. Single-member constituencies also tend to facilitate more personalised electoral competition and electoral connections between legislators and voters but, importantly, they do not allow voters to choose among different party candidates, and party leaders or activists retain strong control over candidate nominations. If, however, the selection of candidates in multi-member constituencies rests with legislative incumbents, party activists, or the electorate, rather than with party leaders (who can favour certain candidates/incumbents over others in list rankings), there will be stronger incentives for legislative individualism than under singlemember constituency systems. ${ }^{69}$

Yet, the empirical evidence on the impact of different electoral rules is inconclusive. ${ }^{70}$ Studies point to the importance of other important factors among systems that share the same ballot structure. Closed list multi-member PR systems - such as those used for elections to the Argentine Cámara de Diputados, the Austrian Nationalrat, the Czech

\footnotetext{
${ }^{68}$ Sartori, Parties and Party Systems: $192 \mathrm{ff}$.

${ }^{69}$ Under PR systems, there is also the possibility of parties favouring particular incumbents in list rankings or by decoupling their election from actual performance in a particular constituency.

${ }^{70}$ Harmel and Janda, Parties and Their Environments, ch. 6 cf. Haspel, Remington, and Smith, 'Electoral Institutions and Party Cohesion in the Russian Duma': 417-39
} 
Poslanecka Snemovna, the Danish Folketing, the German Bundestag, the Dutch Tweede Kamer, the Norwegian Storting, the Swedish Riksdag, the South African National Assembly, or the Venezuelan Asamblea Nacional - seemingly provide legislators with little scope for developing personalised electoral connections and representative styles, because legislative careers are heavily dependent on party leaders who retain centralised control over nomination procedures and decide whether incumbent legislators and other party candidates are placed on the party's electoral list and in what order. ${ }^{71}$ And, in all these legislatures, party cohesion is very strong and party fluidity weak. Contrastingly, in open list PR systems - such as those used for the Italian Camera dei Deputati before 1992, the Brazilian Câmara dos Deputados, the Colombian Cámara de Representantes, and the Uruguayan Parlament - where party leaders have no formal control over the order of candidates' election and voters are able to give their preference votes to candidates not on the party lists, legislators develop strong incentives to develop personal rather than party reputations and their representational strategies are linked to distributive politics; and the effects are to weaken legislative party cohesion. ${ }^{72}$ Single non-transferrable voting systems with personal preference voting and non-pooling of votes (as, for example, Japan's system until 1994), produce similar effects, as do the primary election systems in Israel and the US, which force party candidates to compete with one another and to remain loyal to their local primary voters rather than to national party leaders. ${ }^{73}$

Yet, the interactive effects of electoral rules and party cohesion within the legislature do not end there. For, there is a good deal of evidence that shows that some closed list systems - notably Austria, Belgium, and Venezuela, where parties are programmatically vague and weakly differentiated on major policy issues - generate incentives for legislators to pursue individualistic representational strategies, as in open list systems. ${ }^{74}$

\footnotetext{
${ }^{71}$ E. E. Schattschneider, Party Government. New York: Holt, Rinehart and Winston, 1942: 157; Rasch, 'Electoral Systems, Parliamentary Committees, and Party Discipline': 121-140; Mark P. Jones, 'Explaining the high level of party discipline in the Argentine Congress' in Morgenstern and Nacif, Legislative Politics in Latin America; Michael Coppedge, Strong Parties and Lame Ducks: Presidential Partyarchy and Factionalism in Venezuela. Stanford, CA: Stanford University Press, 1994; Murray and Nijzink, Building Representative Democracy: 14. See also Richard S. Katz, A Theory of Parties and Electoral Systems. Baltimore, MD and London: The Johns Hopkins University Press, 1980: 115-124.

${ }^{72}$ Richard S. Katz, 'Intraparty Preference Voting' in Bernard Grofman and Arend Lijphard, eds., Electoral Laws and Their Political Consequences. New York: Agathon, 1986; and Mainwaring and Shugart, 'Presidentialism and the Party System'; Ames, 'Electoral Strategy under Open-List Proportional Representation'; Sartori, Parties and Party Systems: 93-100; Cf. David J. Samuels, 'Incentives to Cultivate a Party Vote in Candidate-Centric Electoral Systems: Evidence from Brazil', Comparative Political Studies, 32, 199; Matthew S. Shugart, 'Leaders, Rank and File, and Constituents: Electoral Reform in Colombia and Venezuela', Electoral Studies, 11/1, 1992: 21-45; Ingall and Crisp, 'Determinants of Home Style': 487-512.

${ }^{73}$ Mathew D. McCubbins and Frances M. Rosenbluth, 'Party Provision for Personal Politics: Dividing the Vote in Japan' in Peter F. Cowhey and Mathew D. McCubbins, eds., Structure and Policy in Japan and the United States. Cambridge and New York: Cambridge University Press: 33-55; Gary C. Jacobson, The Politics of Congressional Elections. $5^{\text {th }}$ edn. New York and London: Longman, 2001: 11-15; Reuven Y. Hazan, 'Yes, Institutions Matter: The Impact of Institutional Reform on Parliamentary Members and Leaders in Israel' in Longley and Hazan, The Uneasy Relationships Between Parliamentary Members and Leaders: 314-317.

${ }^{74}$ Herbert Kitschelt and Anthony McGann, The Radical Right in Western Europe. Ann Arbor, MI: University of Michigan Press, 1995: 180-184.
} 
Conversely, some parties in open list systems - notably the Brazilian Workers Party in the Câmara dos Deputados, the fujimoristas in the Peruvian Congreso and the Broad Front in the Uruguayan Parlament - as well as legislative parties in the British and Canadian single member systems are as cohesive ${ }^{75}$ as many parties found in closed list multi-member PR systems. The picture is complicated further by the contradictory experiences of legislatures that have mixed electoral systems or have changed their systems. While single-member legislators in Italy's post-1994 and Germany's mixed systems pursue more individualistic representational strategies than their party list colleagues the same is apparently not true of the mixed-member Russian State Duma. Moreover, the shift to a more majoritarian system in Italy has apparently not diminished legislative individualism; while the change to a less majoritarian mixed proportional system for elections to the New Zealand House of Representatives has not significantly affected MPs' dispositions to toe the party line. ${ }^{76}$

Even so, ceterus paribus, there is little question that electoral rules do have pervasive and significant effects. Certain forms provide legislators with better opportunities and stronger incentives to emphasise personal over party reputations, with consequences for cohesion: the weaker central party leaders' control over access to and orderings on ballots, and the larger the numerical size of constituencies (but only if the voting system encourages the cultivation of personal reputations), the greater the propensity for party candidates to be elected by personal votes, regardless of whether or not voters cast a single or a preferential ballot, and the weaker intra-party legislature cohesion becomes.

\section{The Structure of Executive-Legislative Relations}

A second important institutional factor is constitutional. The logic of parliamentary government typically requires cohesive governing parties to facilitate the enactment of the party programme, patronage, and sustain the government. ${ }^{77}$ For individual governing party or coalition legislators, this means sticking with their party in order to maintain the flow of policy and other benefits and in extremis avoiding precipitating new elections in which they may not be reselected or re-elected. In separated systems that accord

\footnotetext{
${ }^{75}$ Ames, 'Party Discipline in the Brazilian Chamber of Deputies'; John M. Carey, 'Transparency Versus Collective Action: Fujimori's Legacy and the Peruvian Congress'. Washington University, St. Louis. Department of Political Science Working Papers, 2003: 1; Scott Morgenstern 'Organized Factions and Disorganized Parties in Uruguay', Party Politics, 7/2, 2001: 235-256; Kam, 'Do Ideological Preferences Explain Parliamentary Behaviour?'

${ }^{76}$ Luca Verzichelli, ' The Uncertain Parliament: The Instability of Party Groups in Italy after 1994', Polichange, 2 , 1999: 6; Newell, 'Turning Over a New Lead?' 45; Thomas F. Remington and Steven S. Smith, 'The Development of Parliamentary Parties in Russia', Legislative Studies Quarterly XX/4, 1995: 481; Frank C. Thames, 'The Effect of District: Russian Single-Member District Deputies and the Constituents' Preferences', The Journal of Legislative Studies, 8/3, 2002: 112; Thomas D. Lancaster And W. David Patterson, 'Comparative Pork-Barrel Politics:

Perceptions From the West German Bundestag', Comparative Political Studies, 22/4, 1990: 458-477; Barker and Levine, 'The Individual Parliamentary Member and Institutional Change: 112-13.

${ }^{77}$ Giovanni Sartori, Comparative Constitutional Engineering: An Inquiry Into Structures, Incentives and Outcomes. Basingstoke and New York: Macmillan: 193.
} 
presidents substantial legislative powers, legislators have fewer incentives to value collective party goods and/or provide legislative support for the executive - because voting against the president and/or losing a particular vote in the legislature does not necessarily weaken the party or the individual legislator's chances of nomination or reelection. Indeed, the logic of separated systems encourages ambitious politicians to seek and gain the highly valued and esteemed office of president independently of legislative party support or sometimes by promoting a new political party. In each case, the effect is to disrupt the cohesion of their legislative party or coalition. ${ }^{78}$ Following a presidential election, moreover, presidents are then obliged to construct discrete partisan or bipartisan supporting coalitions on different policy issues, sometimes on the basis of patronage or a willingness to become presidential clients. ${ }^{79}$ As the experiences in France, Israel, the United States, and various Latin American systems demonstrate, separated systems undermine the primacy of collective representation; weaken legislative party cohesion and other intra-party connections, and produce 'presidentialized parties'. ${ }^{80}$

Again, there is considerable empirical evidence that questions the supposed differential effects of parliamentary and separated systems on legislative party cohesion.

Parliamentary systems differ in more ways than how their members are nominated and elected. ${ }^{81}$ In many parliaments, legislators are sometimes encouraged either by their local party activists (who control nominations) or by local voters to vote against their party; and often they do so with impunity because those activists or voters will continue to support and renominate them. In brief, at least some legislators in parliamentary system are able to cultivate and sustain a personalised electoral connection akin to those found in many separated systems. ${ }^{82}$ Second, there will be situations when party MPs will vote against their government even to the extent of bringing it down, because these outcomes

\footnotetext{
${ }^{78}$ Juan J. Linz, 'Presidentialism or Parliamentarism: Does It Make a Difference?' in Juan J. Linz and Arturo Valenzuela, eds., The Failure of Presidential Democracy. Baltimore, MD and London: The Johns Hopkins University Press, 1994: 1-87; Matthew S. Shugart, 'The inverse relationship between party strength and executive strength: a theory of politicians' constitutional choices', British Journal of Political Science, 28/1, 1998: 1-29; Mainwaring and Shugart, 'Presidentialism and the Party System'; Robert G. Moser, Unexpected Outcomes: Electoral Systems, Political Parties, and Representation in Russia. Pittsburgh, PA: University of Pittsburgh Press, 2001. See also Özbudun, Party Cohesion in Western Democracies: 355-63; Harmel and Janda, Parties and Their Environments: ch. 6; Shaun Bowler, David M. Farrell, and Richard S. Katz, 'Party Cohesion, Party Discipline and Parliaments' in Bowler, Farrell, and Katz, Party Discipline and Parliamentary Government: 3-22.

${ }^{79}$ Leon Epstein, Parties in the American Mold, Madison, WI: University of Wisconsin Press: 84-85; Kaare Strom, 'A Behavioral Theory of Competitive Political Parties', American Journal of Political Science 34/2, 1990 : 583.

${ }^{80}$ David J. Samuels, 'Presidentialized Parties. The Separation of Powers and Party Organization and Behavior', Comparative Political Studies, 35/4, 2002: 461-483; Jon R. Bond and Richard Fleisher, The President in the Legislative Arena. Chicago, IL and London: University of Chicago Press, 1990: chapter 4; Carey. 'Getting Their Way, or Getting in the Way? ': 27; Hazan, 'Yes, Institutions Matter'.

${ }^{81}$ R. Kent Weaver and Bert A. Rockman, 'Assessing the Effects of Institutions' in R. Kent Weaver and Bert A. Rockman. eds., Do Institutions Matter? Government Capabilities in the United States and Abroad, Washington D.C.: The Brookings Institution, 1993: 19-30.

${ }^{82}$ Bruce Cain, John Ferejohn and Morris Fiorina, The Personal Vote. Constituency Service and Electoral Independence. Cambridge, MA and London: Harvard University Press, 1987.
} 
are preferred to the status quo. ${ }^{83}$ In summary, the fusion of the executive and legislature that is supposedly a characteristic feature of parliamentary systems is not always sustained and as a consequence legislative dynamics similar to those found in separated systems come into play. Third, there are sharp differences in legislative efficiency between legislators - say, between the British House of Commons (high) and the Italian Camera or the Korean National Assembly (low). ${ }^{84}$ Intra-party cohesion levels are therefore much more significant in Britain than in Italy or Korea. Fourth, evidence shows that even the most cohesive parliamentary parties experience variations over time, especially as the legislative agenda changes. ${ }^{85}$ Fifth, there is strong evidence that despite the absence of fusion between the executive and the legislature in separated systems presidents exert considerable influence in the legislature, especially in dealing with their own party and especially on budgetary, foreign and national security issues, ${ }^{86}$ which in certain systems (notably Argentina, Brazil, Mexico, and Venezuela,) often amounts to effective presidential control not dissimilar to executive dominance in many parliamentary systems. $^{87}$

For all these reasons then recent theoretical research emphasises more the extent to which and where different political actors exercise veto power over decisionmaking processes and policy choices, and how executives in both parliamentary and separated systems

\footnotetext{
${ }^{83}$ David P. Baron, 'The Dynamics of Parliamentary Government', American Political Science Review, 92/3, 1998: 593-610.

${ }^{84}$ Richard Rose, 'British MPs: More Bark Than Bite' in Ezra N. Soleiman, ed., Parliaments and Parliamentarians in Democratic Politics. New York: Holmes and Maier, 1986; Di Palma, Surviving Without Governing; Giuliani, "Measures of Consensual Law-Making'; Chan Wook Park, 'Change is Short but Continuity is Long: Influence of the National Assembly in Newly Democratized Korea' in Gerhard Loewenberg, Peverill Squire and D. Roderick Kiewiet, eds., Legislatures. Comparative Perspectives on Representative Assemblies. Ann Arbor, MI: The University of Michigan Press: 334, 335, and 339.

${ }^{85}$ See, for example, Philip Norton, Dissension in the British House of Commons, 1974-79. Oxford: Oxford University Press, 1980; Cowley and Norton, 'Rebels and Rebellions': 84-105; Philip Cowley, Revolts \& Rebellions - Parliamentary Voting Under Blair. London: Politico's Publishing, 2002; Robyn B. Wornall, Harmonic Dissidents? An Analysis of Party Cohesion in the German Bundestag. Unpublished PhD Dissertation, University of California, Los Angeles.

${ }^{86}$ Bond and Fleisher, The President in the Legislative Arena: chapter 4; Steven A. Shull, The Two Presidencies: A Quarter Century Assessment. Chicago, IL: Nelson-Hall, 1991.

${ }^{87}$ Michael Coppedge, Strong Parties and Lame Ducks: Presidential Partyarchy and Factionalism in Venezuela. Stanford, CA: Stanford University Press, 1994; Mustapic, 'Oscillating Relations', Octavio Amorim-Neto, 'Presidential cabinets, electoral cycles, and coalition discipline in Brazil', Benito Nacif, 'Understanding Party Discipline in the Mexican Chamber of Deputies: the Centralized Party Model'; Ma. Amparo Casar, ' ExecutiveLegislative Relations: The Case of Mexico (1946-1997)', Jeffrey A. Weldon, 'The Legal and Partisan Framework of the Legislative Delegation of the Budget in Mexico' in Morgenstern and Nacif, Legislative Politics in Latin America; Argelina Cheibub Figueiredo and Fernando Limongi, 'Presidential Power, Legislative Organization, and Party Behavior in Brazil', Comparative Politics, 32/2, 2000: 151-170; Cheibub, Przeworski and Saiegh, 'Government Coalitions Under Presidentialism and Parliamentarism'.
} 
encourage intra-party cohesion through policy appeals, pork barrel, patronage, and other resources that are highly valued by legislators in pursuit of their goals. ${ }^{88}$

\section{Federal systems}

A third major institutional factor is also constitutional. Federalism tends to weaken party cohesion in national legislatures because parties are required to organise on a regional or state basis. Inter-regional and interstate conflicts are then projected into legislative parties at the national level making it more difficult for leaders to construct broad partisan coalitions as legislators heed voters and party leaders in their constituencies. Thus, studies of legislative behaviour in Argentina, Brazil, Nigeria, Russia and the United States show that typically when legislators are cross-pressured between district and party or between local and national party leaders, local influences usually win. ${ }^{89}$

A moment's thought, however, points us to other federal systems where legislative unity is very strong (such as Australia, Canada or Germany) and to non-federal systems (such as Israel) where local control over candidacies is significant and party cohesion is weakened as a consequence. ${ }^{90}$ Moreover, studies of the Argentine Cámara de Diputados, Brazilian Câmara dos Deputados and Senato, and the US House and Senate show that on high salience issues that are important to the majority party leaders are able to devise effective strategies that to some extent reduce the effects of federal and constituency diversity and enhance cohesion. ${ }^{91}$ These findings should not be surprising. They serve to underline how the effects of institutional structures are mitigated by a complex array of political actors and incentives that also influence legislators and their parties. So, federal structure may simply be laid over significant difference in regional political cultures - as, for example, historically between the north and south in the United States. Furthermore, while federalism creates new regional or state political actors and interests that may conflict with national interests, it cannot be assumed that all legislators representing the same state, province or region will have the same partisan affiliations, the same policy preferences, the same types of constituencies or the same influence on a given legislator -

\footnotetext{
${ }^{88}$ Tsebelis, Veto Players: 2-6.

${ }^{89}$ Samuels, 'Progressive Ambition, Federalism, and Pork-Barreling in Brazil'; Kent H. Eaton,' Fiscal Policymaking in the Argentine Legislature' in Morgenstern and Nacif, Legislative Politics in Latin America': 287-314; Scott P. Mainwaring, Rethinking Party Systems in the Third Wave of Democratization: The Case of Brazil. Stanford, CA: Stanford University Press; Ames, 'Electoral Strategy under Open-List Proportional Representation': 406-33; Mainwaring and Pérez-Liñán, 'Party Discipline in the Brazilian Constitutional Congress': 478; Cameron Ross, Federalism and Democratisation in Russia. Manchester: Manchester University Press, 2003; John W. Kingdon, Congressmen's Voting Decisions, Third Edition Ann Arbor, MI: University of Michigan Press, 1989: 289.

${ }^{90}$ Patzelt, 'Party Cohesion and Party Discipline in German Parliaments'; Hazan, 'The Israeli Mixed Electoral System' on the effects of changes in the Israeli system.

${ }^{91}$ Barbara Sinclair, Unorthodox Lawmaking. New Legislative Process in the US Congress. $2^{\text {nd }}$ edn. Washington, D.C.: CQ Press, 2000; Carey, 'Getting Their Way, or Getting in the Way?': 20; Scott W. Desposato, 'The Impact of Federalism on National Party Cohesion in Brazil'. Working Paper, Department of Political Science, University of Arizona, 2003; Jones, 'Explaining the high level of party discipline in the Argentine Congress': 155-158.
} 
and so federalism will interact with localism, local party activists and leaders, the party affiliations of local officials, and party strength among local voters for the support of legislators from the same state. ${ }^{92}$

Any complete examination of the impact of system features on legislative party cohesion would need to include the impact of other institutional features, including legislative voting rules, ${ }^{93}$ forms of legislative organisation (including the decisionmaking authority enjoyed by committees as, for example, in the Italian parliament), ${ }^{94}$ as well as the existence of electronic voting (which makes visible how individual legislators vote and potentially increases their vulnerability to constituency and group over party pressures). ${ }^{95}$ Once again, however, we must expect multiple and interactive causal effects. As crossnational research on electronic voting has shown, much depends on how aware voters are of their representative's legislative voting behaviour, whether or not voters evaluate legislators' performances by their voting records, whether or not other institutional factors are at work providing incentives for voters to reward or punish legislators who support or oppose their national party or president over local constituents, and whether these factors trump the efforts of legislative leaders or presidents to maximise cohesion. ${ }^{96}$

Finally, crossnational comparative research needs to consider the importance of socioeconomic and political cultural factors. Thus, we might surmise that individualistic rather than partisan electoral connections might be particularly characteristic of poorer societies with high levels of illiteracy and low-skilled jobs, little geographic mobility, and few channels of mass communications. In these societies, individual citizens tend not to be so interested in or value highly macro-policies enunciated by programmatic parties; instead voters may find short-term, localised, benefits provided by patrons in exchange for their

\footnotetext{
92 John H. Aldrich and David W. Rohde, 'The Logic of Conditional Party Government: Revisiting the Electoral Connection' in Lawrence C. Dodd and Bruce I. Oppenheimer, eds., Congress Reconsidered. $7^{\text {th }}$ edn. Washington, DC: CQ Press, 2001: 269-292: Wendy J. Schiller, Partners and Rivals. Representation in US Senate Delegations. Princeton, NJ: Princeton University Press, 2000; Brad T. Gomez, 'Power and Homogeneity: Voting Cohesion within State Delegations in the United States House of Representatives', American Politics Quarterly, forthcoming.

${ }^{93}$ In the Canadian House of Commons, for example, every vote is a vote of confidence while in the Finnish Eduskunta a two-thirds majority is required on budget, taxation, and prices and incomes votes. Cecil E.S. Franks, The Parliament of Canada. Toronto: University of Toronto Press, 1987: 99-115; David Arter, Politics and Policy-Making in Finland: A Study of a Small Democracy in a West European Outpost. Basingstoke and New York: Palgrave Macmillan/St Martins, 1987: 43.

${ }^{94}$ Di Palma, Surviving Without Governing: 55-63.

95 Steven S. Smith, Call To Order. Floor Politics in the House and Senate. Washington, DC.: The Brookings Institution, 1989: 28-35, 137; Brandice Canes-Wrone, David W. Brady, and John F. Cogan, 'Out of Step, Out of Office: Electoral Accountability and House Members' Voting', American Political Science Review, 96/1, 2002:127-140.

${ }^{96}$ Carey, 'Visible Votes: Recorded Voting and Legislative Accountability in Latin America'.
} 
votes more attractive. ${ }^{97}$ Similarly, the extent to which a system's political culture upholds individualistic over collective representational and social integration values would likely have a negative effect on legislative party cohesion. Studies of intra-party cohesion in Britain and Denmark, for example, cite 'trust in their party' and 'the best interests of the party' as important values persuading many legislators not to object to decisions whereas other polities would see these values as alien. ${ }^{98}$

Although systemic factors are undoubtedly useful in explaining legislative party unity, they are clearly insufficient to account for much of the variations in legislative cohesion levels both across and within systems.

\section{Party-Level Factors}

A further complicating set of factors impacting intra-party cohesion is the reputations and organisational peculiarities of particular parties within the same system, including how party representation is distributed geographically. Even in those legislatures that exhibit the highest levels of cohesion, it is evidently more difficult to maintain cohesion in some legislative parties rather than others. ${ }^{99}$ Indeed, variance in party unity across parties within single systems may be as great as that across different systems. ${ }^{100}$ Some studies have found that cohesion is correlated with party ideology - left wing parties are usually more cohesive than others - but others have found greater unity in right wing or centrist parties. ${ }^{101}$ Given the benefits of a party controlling the legislative majority and/or the executive in a separated system, and presumably greater access to patronage and other resources with which to influence copartisans, it might be anticipated that intra-party cohesion would be greater within the governing party or coalition than within opposition

\footnotetext{
${ }^{97}$ Herbert Kitschelt, 'Party Cohesion, Accountability, and Responsiveness. Democratic Institutions and PoliticalEconomic Change'. Paper presented to the annual meetings of the American Political Science Association, Washington, DC, 31 August - 3 September, 2002: 18-20; James L. Newell, Parties and Democracy in Italy. Aldershot and Dover, VT: Ashgate, 2000: 182.

98 Özbudun, Party Cohesion in Western Democracies: 339-40, 363-379; Skjæveland, 'Party Cohesion in the Danish Parliament': 38; Crowe, 'The Web of Authority'; Loewenberg, Parliament in the German Political System: 357.

${ }^{99}$ Michael Laver, 'Divided Parties, Divided Government', Legislative Studies Quarterly XXIV/1, 1999: 5-30; Skjæveland, 'Party Cohesion in the Danish Parliament', 42.

${ }^{100}$ Mainwaring and Pérez-Liñán, 'Party Discipline in the Brazilian Constitutional Congress': 474; John M. Carey, 'Parties and Coalitions in the Chilean Congress' in Morgenstern and Nacif, Legislative Politics in Latin America; Carey, 'Party and Coalition Unity in Legislative Voting': 15; Mejía-Acosta, 'Explaining Camistetazos': 12; Hawkins and Morgenstern, 'Cohesion of Legislators in Latin America': 5; Garcl̀a Dìez, 'Electoral Reforms and Central American Legislative Party Systems': 6.

101 Özbudun, Party Cohesion in Western Democracies: 350-353; Sartori, Parties and Party Systems: 192f; Ames, 'Electoral Strategy under Open-List Proportional Representation'; Morgenstern 'Organized Factions and Disorganized Parties in Uruguay' cf. Remington and Smith, 'The Development of Parliamentary Parties in Russia': $479-80$
} 
parties/coalitions. ${ }^{102}$ However, there is little reason to conclude that this would be the case where, as in Brazil, Italy, Japan, and the US, other system features (such as the electoral system and/or presidential influence) encourage legislators to pursue individualistic representational strategies and inhibit parties' capacities to act as cohesive and responsible collectivities. Where governing and opposition parties do offer themselves as cohesive and responsible collectivities, moreover, there is the additional complication that no matter how large the governing party/coalition's legislative majority or indeed, whether it enjoys a majority at all - certain issues will shatter unity and support, especially if the proposed action is unpopular with the voters, as the British Government (with a parliamentary majority of 167) discovered in March 2003 when 138 Labour MPs rebelled against a three-line whip on a vote to go to war with Iraq. Moreover, as the previous discussion suggested, where the same party wins control of a chamber repeatedly, legislators' incentives to remain cohesive may be weak.

Finally, the logic of a party governing or acting as part of a governing coalition might suggest that cohesion will be greater where their legislative majority is small or nonexistent. Under those conditions, leaders will use their powers to keep contentious issues off the agenda and only bring forward those proposals that enjoy majority support within the governing party or coalition; and in parliamentary systems, these dynamics will be reinforced by the higher proportion of the governing coalition being members of the government - or the 'payroll vote' - and, therefore, subject to the additional and more powerful norms of collective responsibility. Where, however, the governing coalition has an overwhelming plurality in the legislature diminishing marginal returns take effect and the number of veto players increases, as the range of values and interests in the party that leaders need to satisfy widens and the scope for defections increases. ${ }^{103}$ In practice, of course, as the earlier discussion showed, legislative leaders may be able to use their powers and skills equally effectively under different pluralities - or even when they are the minority in parliamentary systems - to manipulate legislative situations, shape the legislative agenda, structure decisions and enforce discipline.

\section{Situational Factors}

Finally, we may identify various situational factors that further complicate the effects of system and party factors. The last section touched on the special status of the governing party or coalition, whether it is the majority party in the legislature under a separated

\footnotetext{
${ }^{102}$ Michael Laver and Kenneth A. Shepsle, Making and Breaking Governments: Cabinets and Legislatures in Parliamentary Democracies. Cambridge and New York: Cambridge University Press, 1996; Michael Laver and Norman Schofield, Multiparty Government: The Politics of Coalition in Europe. Cambridge and New York: Cambridge University Press, 1990.

103 Tsebelis, Veto Players and David T. Canon and Kevin S. Price, 'Partisan Policymaking in the United States House of Representatives, 1929-1998.' Paper presented at the Annual Meeting of the American Political Science Association, September 3-6, 1999, Atlanta, GA: 11-12.
} 
system or the majority or minority governing coalition in a parliamentary system. In practice, the significance of a legislative party's governing status is also likely to be affected by the juxtaposition of the governing and opposition parties. The logic of governing status suggests that members of the governing party or coalition will find it easier to stick together when they are opposing either the agenda of the opposition party or the executive (if controlled by the opposing party) than it would be for them to remain cohesive in support of their own cabinet's agenda, particularly if issues are controversial within the party but popular among the electorate. Although the logic for this claim seems strong, there is no systematic crossnational study to support it, only limited evidence from single legislatures. ${ }^{104} \mathrm{~A}$ second important situational factor is the impact of policy on politics: ${ }^{105}$ different types of policies produce different levels of electoral saliency and importance to parties and/or different groups of constituents, which in turn produce different levels of intra party cohesion. ${ }^{106}$ Over time, wholesale agenda changes can produce temporal changes in cohesion levels and even party switching. Again, however, there is no systematic cross-national analysis, only studies of single legislatures. ${ }^{107}$

When, as well as which, issues reach the agenda is also important. Typically, there are strong incentives for party and coalition legislators to stick together immediately following an election victory. Indeed, a number of studies show legislative party cohesion is greater earlier in a legislative term compared with close to a pending election, as the flow of future benefits resulting from unity within the current legislature shrinks and difficult decisions that have been postponed have to be addressed. ${ }^{108}$

\footnotetext{
${ }^{104}$ Philip Norton, Conservative Dissidents London: Temple Smith, 1978; Skjæveland, 'Party Cohesion in the Danish Parliament': 36; Cox and McCubbins, 'Agenda Power in the U.S. House of Representatives': 119-122.

105 Theodore J. Lowi, 'Four Systems of Policy, Politics, and Choice', Public Administration Review, 32/4, 1972: 298-310

${ }^{106}$ Aage R. Clausen, How Congressmen Decide: A Policy Focus. New York: St Martin's Press, 1973; Kingdon, Congressmen's Voting Decisions: ch. 10; Skjæveland, 'Party Cohesion in the Danish Parliament', 40; Patzelt, 'Party Cohesion and Party Discipline in German Parliaments': this volume: xx; Norton, Conservative Dissidents; Cowley and Norton, 'Rebels and Rebellions'; Wearing, 'Tweaking the Whips': 19.

${ }^{107}$ Brady, Cooper, and Hurley, 'The Decline of Party in the US House of Representatives'; Brady and Bullock, 'Party and Factional Organization in Legislatures'; Patterson and Caldeira, 'Party Voting in the United States Congress': 116-7; Norton, Dissension in the British House of Commons; Mershon and Heller. 'Party Fluidity and Legislators' Vote Choices': 18, 24; Remington and Smith, 'The Development of Parliamentary Parties in Russia': 481 .

${ }^{108}$ Cox, The Efficient Secret; Linz, 'Presidentialism or Parliamentarism'; Diermeier and Feddersen, 'Cohesion in Legislatures and the Vote of Confidence Procedure'; Asbjørn Skjæveland, 'A Danish Party Cohesion Cycle', Scandinavian Political Studies, 22, 1999: 121-36; Kurt Richard Luther, 'What Goes Up Always Comes Down? Of Pillars and Arches in Austria's Political Architecture' in Kurt Richard Luther and Kris Deschouwer, eds., Party Elites in Divided Societies. Political Parties in Consociational Democracy. London and New York: Routledge/ECPR Studies in European Political Science, 1999: 63; Sinclair, Legislators, Leaders, and Lawmaking, 210-16.
} 


\section{Conclusion}

Through the medium of purposive theory we can better understand the dynamics of intraparty cohesion within the legislature. In particular, we learn that while there are many benefits for legislators in affiliating and cohering with their parties there are also many costs, which in certain circumstances they are unwilling to bear. When, however, attempts are made to test this theory empirically in a cross-national comparative research design, two common and intractable problems emerge. One is an inability to devise a common and reliable measure of intra-party cohesion, the dependent variable. The second relates to explanations - the independent variables - that are not confined to simplistic differences between parliamentary and supposedly presidential systems, or between different sets of election rules. Rather it is that every legislature has a unique set of formal and informal election rules and internal rules and procedures, is located within a different constitutional and cultural context, and subject to influences emanating from different kinds of policies. In the social science jargon, we have a classic degrees of freedom problem that heavily circumscribes attempts at systematic crossnational comparison. ${ }^{109}$

Even so, the direction in which scholars need to go is clear. As reported here, recent research suggests that many constitutional and institutional distinctions are effectively shorthand for various incentive structures that are built into and develop within different systems. So that the reality of legislative decisionmaking - and therefore intra-party cohesion - is much more complex than constitutional and institutional formalities, and appears to depend more on the extent to which values are shared among copartisans and decisionmaking is coordinated and centralised within political cultures that uphold collective values. On this reading, stronger intra-party cohesion is most likely to emanate from formal and informal processes - including not only disciplinary but also agendasetting processes - that are centrally coordinated either by governing parties or coalitions in parliamentary systems or by presidents and legislative party leaders in separated systems. Weaker cohesion is more likely to be found in systems that are less susceptible to centralised coordination; which are those in which significant nomination and decisionmaking power remains at the local level. ${ }^{110}$

\footnotetext{
${ }^{109}$ Cf. Özbudun, Party Cohesion in Western Democracies; Herbert Kitschelt and Regina Smyth, 'Programmatic Party Cohesion in Emerging PostCommunist Democracies. Russia in Comparative Context', Comparative Political Studies, 35/10, 2002: 1228-56; Carey. 'Getting Their Way, or Getting in the Way?'; and John M. Carey, 'Discipline, Accountability, and Legislative Voting in Latin America', Comparative Politics, 35/2, 2003.

${ }^{110}$ Kitschelt, 'Party Cohesion, Accountability, and Responsiveness'; Jose Antonio Cheibub and Fernando Limongi, 'Modes of Government Formation and the Survival of Democractic Regimes: Parliamentary and Presidential Democracies Reconsidered'. Paper presented to the annual meeting of the American Political Science Association, 30 August - 2 September 2001; Gary W. Cox, 'The Incentive to Build Legislative Parties'. Paper presented to the conference on Political Parties and Legislative Organisation in Parliamentary and Presidential Regimes. Yale University, March 2002.
} 
Notes. 